Bull. Fac. Agric, Cairo Univ.,68:411-424 (2017).

\title{
EVALUATION OF PIONEER AND HOLLYWOOD PLUM CULTIVARS UNDER SANDY SOIL CONDITIONS IN EGYPT
}

\author{
(Received:4.1.2018)
}

\author{
By \\ Y. S. G. Abd Elaziz, *Naglaa H. Shakweer and **Gehan A.M. El-Hadidy \\ Breeding Research Department *Deciduous fruit Research Department and **Fruit Handling \\ Research Department, Horticulture Research Institute, Agriculture Research Center, Giza, Egypt
}

\begin{abstract}
This investigation was conducted for two successive seasons (2013/2014 and 2014/2015) in a private orchard in Regwa district at Giza Governorate, Egypt to evaluate mature trees of "Pioneer and Hollywood" plum cultivars budded on "Nemagard" rootstock. The chosen trees were seven years old, grown in a sandy soil, spaced at 4 X 4 meters apart, irrigated by the drip system. The results revealed that Pioneer was earlier than Hollywood with regard to the phenological studies, which was three to four days earlier for onset of flowering, full bloom and onset of fruit set dates, due to less chilling requirements of Pioneer trees than Hollywood trees to end the dormancy period. While, Pioneer cv. recorded higher number of days from full bloom till maturity date (71\& 91days) and Hollywood cv. recorded ( $61 \& 83$ days) in the both seasons respectively. Hollywood trees were in an upright form with pink blossoms, dark purple foliage, medium-sized and round fruit with rich flavor and blood-red flesh and skin. Pioneer trees were in a spread form with white blossoms, green foliage, bright red skin and the a pale yellow flesh. Regarding the vegetative growth traits, it was noticed that Hollywood cv. attained the highest significant values of shoot diameter and length, leaf number, leaf area and total chlorophyll as compared to Pioneer in both seasons. With respect to yield attributes and fruit physiochemical characteristics, Pioneer cv. was the significant highest values of yield, fruit weight and dimensions, whereas Hollywood cv. had significantly the highest percentage of the total soluble solids and the lowest percentage of acidity in both seasons. Concerning histological studies, the two cultivars showed similar levels of partially self-incompatible. Pioneer cv. had a higher degree of partial self-incompatibility than Hollywood cv. So, they need additional cultivars as pollinators for good growing and fruiting. As for the storability, it was clear that Pioneer and Hollywood fruits kept a good characteristics, expressed decrease of fruit weight loss and improvement of fruits physical and chemical characteristics, including the increase of fruit color, total soluble solids and the decrease of juice acidity during cold storage period at $2{ }^{\circ} \mathrm{C}$ and $90-95 \% \mathrm{RH}$ for three weeks. Therefore, the widespread cultivation of these two cultivars in Egypt is recommended.
\end{abstract}

Key words: Plum cvs., vegetative criteria, yield, self-compatibility, fruit quality, storability.

\section{INTRODUCTION}

Plum, (Prunus salicina L.) is one of the deciduous fruit trees cultivated in Egypt. The total area planted with plum reached about 2,614 feddans with annual production of about 13,941 tons, (Ministry of Agriculture Statistics, Egypt, 2015). The reduction in the cultivated area and average productivity could be due to the unfavorable weather conditions during blossoming, which results in decreasing insect activity and pollination, especially for selfincompatible varieties. Plums and apricots blossom is early, in spring, where weather conditions are less predictable and often unfavorable for the activity of insect pollen vectors, particularly to self-sterile cultivars which require cross pollination for effective fruit set (Webster and Spencer, 2000). Hollywood plum is one of the Japanese varieties that grows well under the Egyptian environmental conditions due to their low chilling requirements compared to the European plums (Abdel-Sattar et al., 2013). Pioneer is an early red-skinned plum variety. Skin is bright red and the flesh is pale yellow. Pioneer was bred by Infuriate in South Africa, released in 1995 (Maklad and Ismaile, 2016). 
The important factor for successful plum growing is the knowledge of the cultivar's degree of self-fertility. Diploid plum species such as Prunus salicina L. and Prunus cerasifera E., are mostly self-incompatible. While, fertility relations of the hexaploid European plum (Prunus domestica L.) varieties vary between self-fertility, partial self-fertility and self-incompatibility (Szabó, 2003).

Regarding production practice and breeding, self-fertile varieties are of the highest value, because growing partially self-fertile, self-incompatible and self-sterile varieties necessitate providing adequate pollinators. Self-compatibility is usually determined by monitoring fruit set in pollinated and isolated flowers under field conditions. The disadvantage of this method is that fruit set varies from year-toyear depending on weather conditions, rootstocks, nutrition, pruning and health status of the tree (Pejkić, 1978).

Another method used, is the pollination of flowers and observation of pollen tube growth in the style under fluorescent microscope. It enables reliable conclusions regarding the selfcompatibility (Viti et al., 1997).

Proper maturity at harvest and right handling are essential for marketing good quality of stone fruits. Postharvest changes in fresh fruits cannot be prevented but they can be slowed down within certain limits by using various procedures that retard ripening such as low temperatures, packaging and some coating materials, (Perez et al., 2004). The major factors limiting shelf life of plums are their softening, fungi decay, reduced flavor quality (too low acidity, no aroma) and less favorable appearance like shriveling or bruising (Vangdal et al., 2007).

The goals of this study were :1) to evaluate the two plum cultivars, Pioneer and Hollywood, in terms of the vegetative growth, flower and fruit characteristics, yield and fruit quality attributes as well as, storability under sandy soil conditions in Egypt, and 2) to examine selfincompatibility of Hollywood and Pioneer cultivars to determine the need for these varieties to grow with other varieties in the same orchard as pollinators.

\section{MATERIALS AND METHODS}

The present investigation was conducted at a private orchard in Regwa district at Giza Governorate, Egypt. The experiment extended for two successive seasons (2013/2014 and 2015) on mature trees of "Pioneer and Hollywood"plum cultivars.
Nine trees (seven year old) per cultivar, spaced $4 \times 4 \mathrm{~m}$ grown in a sandy soil were randomly selected, with approximate vigorous uniform vegetative growth, and budded on "Nemagard" rootstock. Regular horticultural practices were applied to all the experimental trees.

\subsection{Chilling requirements (Meteorological data)}

Chill units from leaves defoliation till beginning of flowering as obtained from the Central Laboratory of Agricultural Climate (CLAC) ARC, Egypt were recorded as the number of hours $\left(<7.2{ }^{\circ} \mathrm{C}\right.$ and $\left.<10{ }^{\circ} \mathrm{C}\right)$.

\subsection{Phenological studies}

Four shoots of the current season in four directions were tagged on nine trees/cultivar to record:

a-Time of phenological dates (onset of flowering, full bloom, onset of fruit set and fruit maturity) was recorded periodically.

b-Number of days for phenological dates was calculated periodically by calendar year.

The morphological studies were carried out according to the International Amelographic Registered Schedule as following: fruit dimensions, fruit color and flesh color.

\subsection{Vegetative growth characteristics}

Eight branches, as similar as possible, were chosen at the four cardinal points of each cultivar tree, tagged and the average of shoot diameter $(\mathrm{cm})$, shoot length $(\mathrm{cm})$, leaves number, leaf area $\left(\mathrm{cm}^{2}\right)$ and the total chlorophyll was determined by using (SPAD) meter (Minolta Corporation, Ramsey, NJ, USA).

\subsection{Yield and fruit physical and chemical characteristics}

Ten, one year old, shoots per tree were randomly chosen at dormant stage; i.e. the following parameters were calculated according to the following equation:

Fruit set $\%=$ (Total No. of fruit lets/Total No. of flowers ) X100

Yield/tree $(\mathrm{kg})$ was determined as the number of fruits/tree $X$ average fruit weight (g). Also, twenty fruits per tree samples were examined at picking date to determine fruit characteristics including: fruit weight $(\mathrm{g})$, fruit length $(\mathrm{cm})$ and fruit diameter were measured. Total soluble solids (\%) were estimated using hand refractometer and total acidity was estimated according to (A.O.A.C., 2000).

\subsection{Histological studies}

\subsubsection{Relationship between stamen number/pistil length ratio and the fertility of two plum cultivars flowers}


Number of stamens in flowers for each cultivar under study as well as pistil length $(\mathrm{mm})$ were determined in order to calculate the stamen number (SN)/pistil length (PL) ratio. Each cultivar was represented by 5 replicates. Each replicate contained 50 flowers randomly selected. Moreover, fruit set after self-pollination was correlated with the $\mathrm{SN} / \mathrm{PL}$ ratio to determine the degree of self-fertility of these cultivars.

\subsubsection{Viability of pollen grains}

Pollen grains were collected to determine the viability and self-pollination. The flowers of both cultivars were collected at the balloon stage, one day before anthesis. In order to let the anthers dehisce, the flowers were placed on paper in the laboratory at room temperature. After one day, pollen grains of each cultivar were separately collected in glass tubes.

Pollen viability was determined using 2,3 , 5,-triphenyltetrazolum chloride (TTC) staining solution. 1 part $10 \%$ TTC; 10 part $60 \%$ sucrose solution according to the methods described by Oberle and Watson, (1953).

\subsubsection{Self-compatibility and Pollen tube growth}

Seventy flowers were used, distributed over 2 or 3 trees. The hand pollination was carried out according to the method described by Wertheim (1996).

Fixation of pistils was done daily for seven successive days after pollination. Fixation was carried out with FAA fixative consisting of $70 \%$ ethanol, glacial acetic acid and formaldehyde in the ratio 90:5:5 (Burgos et al., 1997). Fixed material was kept at $4^{\circ} \mathrm{C}$ in the refrigerator until staining. Before staining, pistils were rinsed in running water for 24 hour. Thereafter, they were immersed in $8 \mathrm{~N}$ solution and left to 2 hour to soften their tissues. This procedure was followed to facilitate the penetration of stain solution and the preparation of flowers. pistils were washed from $\mathrm{NaOH}$ overnight in running tap water. Finally, staining was done with $0.1 \%$ aniline blue dissolved in $0.1 \mathrm{~N}_{3} \mathrm{KO}_{4}$. The vials containing the material were kept at $4{ }^{\circ} \mathrm{C}$ until the microscopic examination according to the method of Kho and Baer (1968). The fluorescence under ultraviolet light allows the pollen tube to be traced through the style tissue and identifies the rejection site. This technique had been already described by Martin, (1959).

To prepare pistils for microscopic examination, the style was separated from the ovary. The style was squashed, while the ovary was cut longitudinally with a razor blade so that penetration of pollen tubes into the ovules could be seen. The examination of pistils was done under the fluorescent microscope.

\subsubsection{Initial fruit set and fruiting percentages}

As mentioned in the pollination treatment, about 450 flowers per each treatment were left for fruit set measurements. The numbers of the total flowers were counted at anthesis. Moreover, the fruits were counted after 15 to 21 days from pollination (Initial fruit set). Percentage of the initial fruit set was calculated as follows:

Initial fruit set $\%=$ number of set fruits/total number of flowers $x 100$

Fruiting percentage was determined by counting the number of final remained fruits (before the date of harvest). Percentage of fruiting was calculated as follows:

Fruiting percentage $=$ the number of final fruits / total number of flowers $x 100$

Nyéki and Szabó (1996) established five groups of cultivars: entirely self-incompatible (fruit set $0 \%$ ), self-incompatible (fruit set from $0.1 \%$ to $1 \%$ ), partially self-fertile (fruit set $1,1 \%$ to $10 \%$ ), self-fertile (fruit set from $10.1 \%$ to $20 \%$ ) and highly self-fertile (fruit set above 20\%).

\subsection{Storability studies}

Plum fruits were picked at maturity stage according to previous studies in this investigation when T.S.S. were $15.3,16.3$ for pioneer and Hollywood, respectively. Fruits were packed in perforated polypropylene bags, each containing 550- $650 \mathrm{~g}$, then packed in carton boxes, each containing three bags. 12 boxes of each cultivar were storied at $2{ }^{\circ} \mathrm{C}$ and $90-95 \%$ RH for three weeks. Samples were examined at initial and every week for the following changes in physical and chemical characteristics.

\subsubsection{Physical characteristics}

1.Weight loss (\%) per box was determined periodically according to the equation (weight loss X $100 /$ the initial weight of box).

2.Decay (\%) per box was calculated periodically according to the equation (weight of decayed $\mathrm{X}$ $100 /$ the initial weight of box).

3. Fruit firmness $\left(\mathrm{Lb} / \mathrm{inch}^{2}\right)$ was estimated on ten fruits through the use of texture analyzer instrument using a penetrating Cylinder of 1 $\mathrm{mm}$ diameter to a constant distance $1 \mathrm{~mm}$ inside the berry skin by a constant speed $2 \mathrm{~mm}$ per sec. and the peak of the resistance force of the skin was recorded periodically. 
4.Fruit color: Intensity of color was measured by Konick Minolta, Chroma Meter CR-400/410 for the estimation of Hue angle as described by MCgurie (1992).

\subsubsection{Chemical characteristics}

1.Percentage of total soluble solids in fruit juice (TSS) was recorded periodically using a hand refractometer.

2.Percentage of total acidity was also determined periodically (A.O.A.C., 2000).

\subsection{Statistical analysis}

The completely randomized design was adopted for this investigation. The obtained data were statically analyzed using the $\mathrm{T}$ test according to Steel and Torrie (1980) for field experiment and using New L.S.D. test at 5\% level for storability experiment according to Snedecor and Cochran (1980).

\section{RESULTS AND DISCUSSION 3.1. Accumulated chilling units}

Table (1) showed accumulated chilling units at El-Tahrir location, Alexandria $(60 \mathrm{~km}$ CairoAlexandria Desert Road), calculated by two different methods $\left(<7{ }^{\circ} \mathrm{C}\right.$ and $\left.<10{ }^{\circ} \mathrm{C}\right)$ during the two seasons 2013/2014 and 2014/2015.

The highest accumulated chilling units to break bud dormancy of Hollywood cv. at $<10$
These variations in dates from blooming to harvest of both cultivars may be due to genotypic differences. These findings were in agreement with those of Khalil and El-Sheik (2000) on apricot, Carter et al. (2003), Yahia et al. (2010) on peach and Maklad and Ismaile (2016) on plum.

\subsection{Vegetative growth characteristics}

Data in Table (3) revealed that some vegetative growth traits expressed as shoot diameter, length, leaves number, leaf area and total chlorophyll were significantly affected by type of cultivar, where Hollywood cv. attained significantly the highest values of shoot diameter $(0.87$ and $0.83 \mathrm{~cm})$, shoot length $(21.07$ and $18.11 \mathrm{~cm})$, leaves number $(25.97$ and 23.61$)$, leaf area $\left(32.14\right.$ and $\left.31.37 \mathrm{~cm}^{2}\right)$ and total chlorophyll (47.53 and 46.21), at the two seasons, respectively. While Pioneer cv. produced significantly the least values of shoot diameter $(0.79$ and $0.74 \mathrm{~cm})$, shoot length $(19.31$ and $15.24 \mathrm{~cm}$ ), leaves number (22.19 and 21.04$)$, leaf area $\left(29.86\right.$ and $\left.27.64 \mathrm{~cm}^{2}\right)$ and total chlorophyll (43.67 and 44.38) in both seasons, respectively.

These findings are in agreement with those of Khalil and El-Sheik (2000) on apricot, Carter et al., (2003), Yahia et al., (2010) on peach and Maklad and Ismaile (2016) on plum.

Table (1): Accumulated chilling units for Pioneer and Hollywood plum cultivars during 2013/2014 and 2014/2015 seasons.

\begin{tabular}{|l|c|c|c|c|}
\hline \multirow{2}{*}{ Cultivar } & \multicolumn{2}{|c|}{ Season 1 } & \multicolumn{2}{c|}{ Season 2 } \\
\cline { 2 - 5 } & $<7^{\circ} \mathbf{C}$ & $<\mathbf{1 0}^{\circ} \mathbf{C}$ & $<7^{\circ} \mathbf{C}$ & $<\mathbf{1 0}^{\circ} \mathbf{C}$ \\
\hline Pioneer & $\mathbf{1 0 5}$ & $\mathbf{3 5 7}$ & 187 & 457 \\
\hline Hollywood & 105 & $\mathbf{3 6 6}$ & 193 & 472 \\
\hline
\end{tabular}

${ }^{\circ} \mathrm{C}$ in the first season, also, at $<7{ }^{\circ} \mathrm{C}$ and $<10{ }^{\circ} \mathrm{C}$ in the second season, in comparison with Pioneer cv.

\subsection{Phenological studies}

Data in Table (2) showed the differences among the phenological dates (onset flowering, full bloom, onset fruit set and fruit maturity) of Pioneer and Hollywood cv.'s observed in both seasons. Pioneer cv. was earlier than Hollywood (around three to four days), for onset of flowering, full bloom and onset fruit set dates, due to the fact that Pioneer trees need less chilling requirements than Hollywood trees to end the dormancy period of the trees. While, Hollywood cv. was fife to seven days earlier than Pioneer for fruit maturity date.

\subsection{Descriptive measurements}

The morphological description was illustrated in Fig. (1) according to the International Amelographic Registered Schedule as follows:

Hollywood plum is an early, up right from medium size tree, dark purple foliage, pink blossoms, medium-sized and round, fruits richly flavored with blood-red flesh, and the skin and the seed are separate, or loose.

Pioneer plum is an early, spread form large size tree, green foliage, white blossoms, fruit is big-sized and round, bright red skin with pale yellow flesh and the seed is semi-adherent. These results are in concordance with those obtained by Maklad and Ismaile (2016). 
Table (2):Times of dates and the number of days by calendar year for dates of onset flowering, full bloom and onset fruit set for Pioneer and Hollywood plum cultivars in (2013-2014 and 2014- 2015 seasons.

\begin{tabular}{|c|c|c|c|c|c|c|c|c|}
\hline \multicolumn{9}{|c|}{ Pioneer plum cultivar } \\
\hline & \multicolumn{2}{|c|}{ Onset of flowering } & \multicolumn{2}{|c|}{ Full bloom } & \multicolumn{2}{|c|}{ Onset of fruit set } & \multicolumn{2}{|c|}{ Fruit maturity } \\
\hline & $\begin{array}{c}1^{s t} \\
\text { season }\end{array}$ & $\begin{array}{c}2^{n d} \\
\text { season }\end{array}$ & $\begin{array}{c}\mathbf{1}^{\text {st }} \\
\text { season }\end{array}$ & $\begin{array}{c}2^{n d} \\
\text { season }\end{array}$ & $\begin{array}{c}\mathbf{1}^{\text {st }} \\
\text { season }\end{array}$ & $\begin{array}{c}2^{n d} \\
\text { season }\end{array}$ & $\begin{array}{c}\mathbf{1}^{\text {st }} \\
\text { season }\end{array}$ & $\begin{array}{l}2^{n d} \\
\text { seaso } \\
\mathrm{n}\end{array}$ \\
\hline Dates & $\begin{array}{c}1 \\
\text { Mar. }\end{array}$ & $\begin{array}{c}2 \\
\text { Feb } \\
\end{array}$ & $\begin{array}{c}15 \\
\text { Mar. }\end{array}$ & $\begin{array}{c}25 \\
\text { Feb. }\end{array}$ & $\begin{array}{c}20 \\
\text { Mar. }\end{array}$ & $\begin{array}{c}27 \\
\text { Feb. } \\
\end{array}$ & $\begin{array}{c}25 \\
\text { May } \\
\end{array}$ & $\begin{array}{c}27 \\
\text { May } \\
\end{array}$ \\
\hline No. of days & 60 & 33 & 74 & 56 & 79 & 58 & 145 & 147 \\
\hline \multicolumn{9}{|c|}{ Hollywood plum cultivar } \\
\hline & \multicolumn{2}{|c|}{ Onset of flowering } & \multicolumn{2}{|c|}{ Full bloom } & \multicolumn{2}{|c|}{ Onset of fruit set } & \multicolumn{2}{|c|}{ Fruit maturity } \\
\hline & $\begin{array}{c}1^{\text {st }} \\
\text { season }\end{array}$ & $\begin{array}{c}2^{n d} \\
\text { season }\end{array}$ & $\begin{array}{c}1^{\text {st }} \\
\text { season }\end{array}$ & $\begin{array}{c}2^{n d} \\
\text { season }\end{array}$ & $\begin{array}{c}1^{\text {st }} \\
\text { season }\end{array}$ & $\begin{array}{c}2^{n d} \\
\text { season }\end{array}$ & $\begin{array}{c}1^{\text {st }} \\
\text { season }\end{array}$ & $\begin{array}{l}2^{\text {nd }} \\
\text { seaso } \\
\text { n }\end{array}$ \\
\hline Dates & $\begin{array}{c}5 \\
\text { Mar. }\end{array}$ & $\begin{array}{c}5 \\
\text { Feb. }\end{array}$ & $\begin{array}{c}18 \\
\text { Mar. }\end{array}$ & $\begin{array}{c}28 \\
\text { Feb. }\end{array}$ & $\begin{array}{c}23 \\
\text { Mar. }\end{array}$ & $\begin{array}{c}1 \\
\text { Mar. }\end{array}$ & $\begin{array}{c}18 \\
\text { May }\end{array}$ & $\begin{array}{c}22 \\
\text { May }\end{array}$ \\
\hline No. of days & 64 & 36 & 77 & 59 & 82 & 60 & 138 & 142 \\
\hline
\end{tabular}

Table (3): Vegetative growth characteristics for Pioneer and Hollywood plum cultivars in 20132014 and 2014-2015 seasons.

\begin{tabular}{|l|c|c|c|c|c|}
\hline \multicolumn{1}{|c|}{ Cultivar } & $\begin{array}{c}\text { Shoot } \\
\text { diameter }(\mathbf{c m})\end{array}$ & $\begin{array}{c}\text { Shoot } \\
\text { length }(\mathbf{c m})\end{array}$ & $\begin{array}{c}\text { Number } \\
\text { of leaves }\end{array}$ & $\begin{array}{c}\text { Leaf } \\
\text { area }\left(\mathbf{c m}^{2}\right)\end{array}$ & $\begin{array}{c}\text { Total chlorophyll } \\
\text { (SPAD) }\end{array}$ \\
\hline \multicolumn{7}{|c|}{$\mathbf{1}^{\text {st }}$ season } \\
\hline Pioneer & $\mathbf{0 . 7 9}$ & $\mathbf{1 9 . 3 1}$ & $\mathbf{2 2 . 1 9}$ & $\mathbf{2 9 . 8 6}$ & $\mathbf{4 3 . 6 7}$ \\
\hline Hollywood & $\mathbf{0 . 8 7}$ & $\mathbf{2 1 . 0 7}$ & $\mathbf{2 5 . 9 7}$ & $\mathbf{3 2 . 1 4}$ & $\mathbf{4 7 . 5 3}$ \\
\hline T. test & S. & S. & S. & S. & S. \\
\hline \multicolumn{7}{|c|}{$\mathbf{2}^{\text {nd }}$ season } \\
\hline Pioneer & $\mathbf{0 . 7 4}$ & $\mathbf{1 5 . 2 4}$ & $\mathbf{2 1 . 0 4}$ & $\mathbf{2 7 . 6 4}$ & $\mathbf{4 4 . 3 8}$ \\
\hline Hollywood & $\mathbf{0 . 8 3}$ & $\mathbf{1 8 . 1 1}$ & $\mathbf{2 3 . 6 1}$ & $\mathbf{3 1 . 3 7}$ & $\mathbf{4 6 . 2 1}$ \\
\hline T. test & S. & S. & S. & S. & S. \\
\hline S. (Significant) & & & & \\
\hline
\end{tabular}

3.5. Yield and fruit physical and chemical characteristics

As shown in Table (4), showed the variation occurred in fruit set percentage, yield attributes and fruit physiochemical characteristics of Pioneer and Hollywood cv.'s in both seasons.

Concerning the percentage of fruit set, the data revealed that insignificant differences were noted between Pioneer and Hollywood cultivars in both seasons. With respect to yield, Pioneer cultivar exhibited the highest significant value of yield, which was $(52.69$ and $49.32 \mathrm{~kg} /$ tree at the two seasons, respectively), whereas Hollywood cultivar had significantly the lowest value of this estimate, which was 13.57 and $12.94 \mathrm{~kg} /$ tree in both seasons, respectively. Regarding fruit weight, Pioneer cultivar attained the highest significant value of fruit weight, (74.53 and $73.27 \mathrm{~g}$ ), while Hollywood cultivar produced significantly the lowest value of this one, (41.29 and $39.83 \mathrm{~g}$ ) in both seasons, respectively. Concerning fruit dimensions, the data showed that Pioneer plum cultivar resulted in significantly the highest values of fruit length 


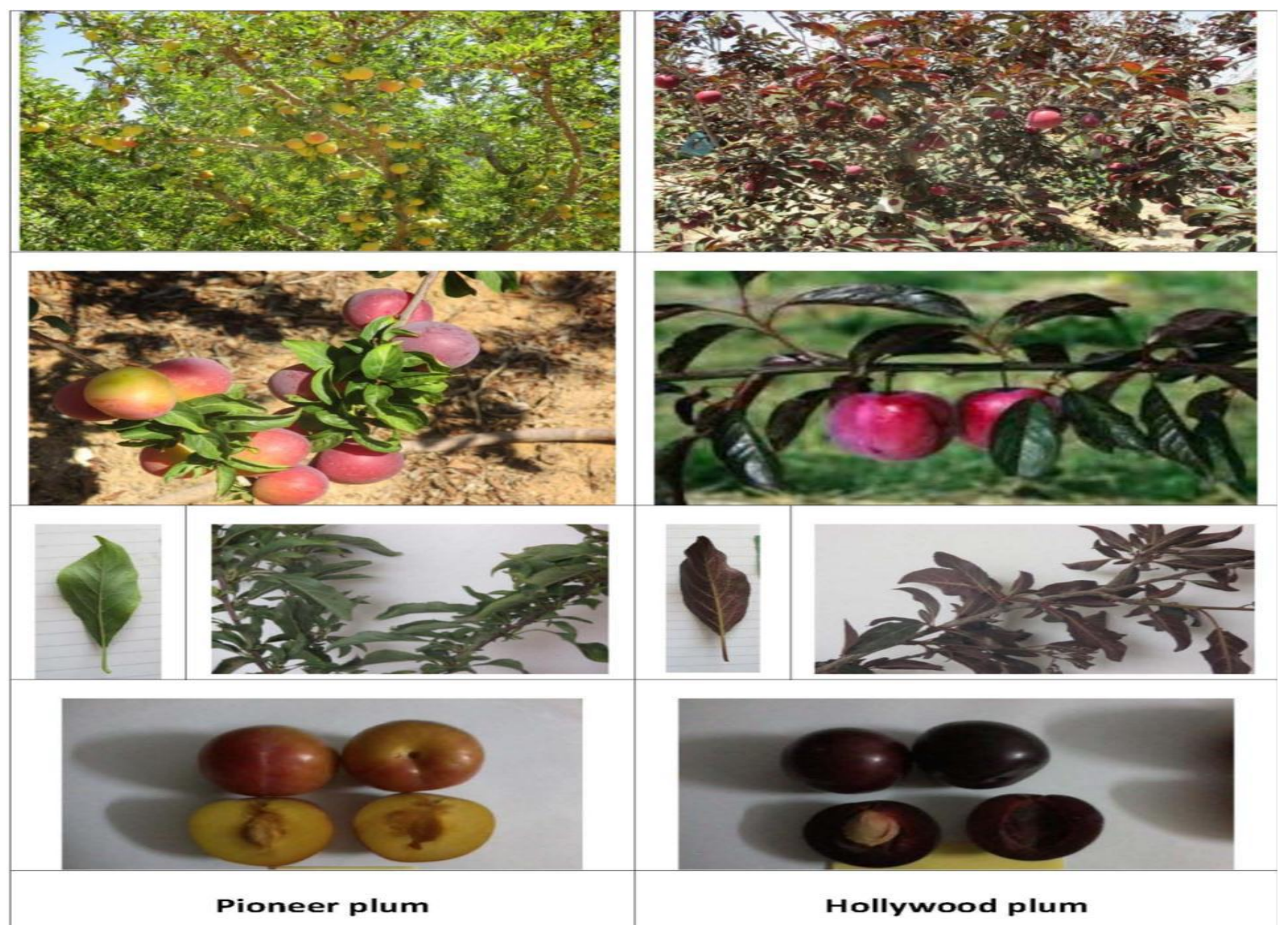

Fig.(1) : The morphological description of Pioneer and Hollywood plum cultivars

Table (4): Yield and fruit physical and chemical characteristics for Pioneer and Hollywood plum cultivars in 2013/2014 \& 2014/2015 seasons.

\begin{tabular}{|c|c|c|c|c|c|c|c|}
\hline Cultivar & $\begin{array}{c}\text { Fruit } \\
\text { set }(\%)\end{array}$ & $\begin{array}{c}\text { Yield/ } \\
\text { tree } \\
(\mathrm{kg})\end{array}$ & $\begin{array}{c}\text { Fruit } \\
\text { weight (g) }\end{array}$ & $\begin{array}{l}\text { Fruit length } \\
\text { (cm) }\end{array}$ & $\begin{array}{c}\text { Fruit } \\
\text { diameter } \\
(\mathrm{cm})\end{array}$ & $\begin{array}{l}\text { T.S.S } \\
(\%)\end{array}$ & $\begin{array}{c}\text { Total } \\
\text { acidity } \\
(\%) \\
\end{array}$ \\
\hline \multicolumn{8}{|c|}{$\mathbf{1}^{s t}$ season } \\
\hline Pioneer & 13.53 & 52.69 & 74.53 & 5.19 & 4.92 & 15.32 & 1.63 \\
\hline Hollywood & 13.64 & 13.57 & 41.29 & 4.23 & 4.09 & 16.37 & 1.51 \\
\hline T. test & N.S. & S. & S. & S. & S. & S. & S. \\
\hline \multicolumn{8}{|c|}{$2^{n d}$ season } \\
\hline Pioneer & 12.87 & 49.32 & 73.27 & 4.98 & 4.83 & 15.09 & 1.66 \\
\hline Hollywood & 12.92 & 12.94 & 39.83 & 4.17 & 4.04 & 16.13 & 1.57 \\
\hline T. test & N.S. & S. & S. & S. & S. & S. & S. \\
\hline \multicolumn{8}{|c|}{ S. (Significant) $\quad$ N.S. (Non-Significant) } \\
\hline
\end{tabular}


(5.19 and $4.98 \mathrm{~cm})$ and fruit diameter, (4.92 and $4.83 \mathrm{~cm}$ ) whereas Hollywood cultivar had significantly the lowest values of fruit length (4.23 and $4.17 \mathrm{~cm}$ ) and fruit diameter (4.09 and $4.04 \mathrm{~cm}$ ) in both seasons, respectively.

Regarding juice TSS\%, the data revealed that Hollywood attained significantly the highest percentage of juice TSS (16.37 and $16.13 \%$ ). Pioneer produced significantly the lowest percentage (15.32 and $15.09 \%)$ in both seasons, respectively.

Concerning juice total acidity, Hollywood plum cultivar resulted in significantly the lowest percentage of acidity (1.51 and 1.57\%), whereas Pioneer cultivar had significantly the highest percentage of this estimate, (1.63 and 1.66\%) in both seasons respectively.

These results are in accordance with those obtained by Carter et al., (2003), Yahia et al., (2010), on peach Maklad \& Ismaile (2016) and Thanaa et al. (2017) on plum.

\subsection{Histological studies}

\subsubsection{Stamen number $(\mathrm{SN})$ and pistil length} (PL)

Data presented in Table (5) indicated that significant differences occurred in stamen number in the first season, whereas Hollywood cv. gave a value higher than Pioneer cv. (32.5\& 29.8 respectively,), while in the second season there were non-significant differences in stamen number for the two cultivars. Likewise, significant variations were detected for the two cultivars in terms of pistil length. The highest pistil length was obtained in Hollywood cv. (ranged between 9.19 to $8.65 \mathrm{~mm}$,), while it ranged between 7.64 to $7.34 \mathrm{~mm}$ for Pioneer cultivar in the first and the second seasons, respectively.

\subsubsection{Initial fruit set and fruiting percentage after self-pollination}

Data presented in Table (6) illustrated that self-pollination significantly affected the percentage of initial fruit set as well as fruiting. It is clearly shown that both initial fruit set and fruiting of Hollywood cv. were higher than Pioneer $\mathrm{cv}$. in both seasons of the study.

\subsubsection{Relationship between (SN/PL) ratio and fruiting percentage}

Concerning the relationship between SN/PL ratio and fertility, Table (7) clearly showed that Pioneer cv. had a higher value of SN/PL ratio than Hollywood cv., while its selfing showed a value of fruiting percentage significantly lower than Hollywood cv. in the first season. Furthermore, Pioneer cv. showed a value of SN/PL ratio significantly higher than Hollywood $\mathrm{cv}$. while its selfing had a value of fruiting percentage lower than Hollywood cv. in the second season. It seems that partial self-fertile cultivars have longer pistil than low-fertile $\mathrm{cv}$. and low self-fertile cultivars have more stamens than partial self-fertile ones. Also, SN/PL ratio is significantly higher in low-fertile than partial self-fertile cultivars.

The obtained results are in harmony with the findings of Surranyi (1976) who reported that in plum (Prunus domestica) SN/PL ratio is lower in self-fertile than in self-sterile cv. In addition, Abd Elaziz (2005) postulated that high selffertile cultivars have longer pistil than low selffertile cv. and the low self-fertile cultivar has more stamens than high self-fertile ones. Also,

Table (5): Stamen number (SN) and pistil length (PL) of Hollywood and Pioneer cultivars in 2013/2014 and 2014/2015 seasons.

\begin{tabular}{|c|c|c|c|c|}
\hline \multicolumn{2}{|c|}{ Cultivars } & \multicolumn{2}{|c|}{ Stamen number } & \multicolumn{2}{c|}{ Pistil length } \\
\cline { 2 - 5 } season & $\mathbf{1}^{\text {st }}$ season & $2^{\text {nd }}$ season & $\mathbf{1}^{\text {st }}$ season & $2^{\text {nd }}$ season \\
\hline Hollywood & 32.5 & 31.1 & 9.19 & $\mathbf{8 . 6 5}$ \\
\hline Pioneer & 29.8 & 30.6 & 7.64 & 7.34 \\
\hline T.test & S & NS & S & S \\
\hline
\end{tabular}

Table (6): Initial fruit set and fruiting percentage of Hollywood and Pioneer cultivars after self-pollination in 2013/2014 and 2014/2015 seasons.

\begin{tabular}{|l|c|c|c|c|}
\hline Cultivars Season & $1^{\text {st }}$ season & $2^{\text {nd }}$ season & $1^{\text {st }}$ season & $2^{\text {nd }}$ season \\
\hline Hollywood & 36.317 & 31.923 & 5.160 & 4.753 \\
\hline Pioneer & 9.727 & 10.440 & 2.387 & 1.400 \\
\hline T. test & $\mathrm{S}$ & $\mathrm{S}$ & $\mathrm{S}$ & $\mathrm{S}$ \\
\hline
\end{tabular}


Table (7): Relationship between (SN/PL) ratio and fruiting percentage of Hollywood and Pioneer cultivars after self-pollination in 2013/2014 and 2014/2015 seasons.

\begin{tabular}{|c|c|c|c|c|}
\hline \multirow[t]{2}{*}{ Cultivars } & \multicolumn{2}{|c|}{ SN/PL } & \multicolumn{2}{|c|}{ Fruiting } \\
\hline & $1^{s t}$ season & $2^{n d}$ season & $1^{s t}$ season & $2^{n d}$ season \\
\hline Hollywood & 3.544 & 3.606 & 5.160 & 4.753 \\
\hline Pioneer & 3.981 & 4.202 & 2.387 & 1.400 \\
\hline T. test & NS & $\mathbf{S}$ & $\mathbf{S}$ & S \\
\hline
\end{tabular}

SN/PL ratio is significantly higher in low-fertile cv. than in high self-fertile cultivars.

\subsubsection{Viability of pollen grains}

Data in Table (8) clearly postulated that pollen viability of Hollywood and Pioneer cvs. showed high rates of viability in both studied seasons but there was no significant difference between cultivars in the first season. On the contrary, Hollywood cv. exhibited significantly higher viability of pollen grains than Pioneer cultivars in the second season.

These results are similar to those obtained by Abd Elaziz (2005) found that pollen of the three plum cultivars Santa-Rosa, Durado and Eldorado showed high rates of viability. Durado cv. had the highest rate of pollen viability in comparison with other cultivars. pollen tube growth. However, most of the pollen tubes, which grew through the styles characterized by spaced intermittent callose plugs along the tube, and they reach the base of the style in 4 days after pollination.

3.6.7. Pollen tube characteristics after selfpollination (selfing) of Pioneer cv.

Although most of the pollen grains germinated on the stigma surface, the pollen tube grew slowly with heavy deposition of callose along the tube where its growth stopped in the lower part of the style 4 days after pollination. However the lowest number of examined pistils had at least one pollen tube reached the base of the style. Based on the obtained results, the two studied cultivars showed similar levels of partially self-

Table (8): Percentage of pollen viability of Hollywood and Pioneer cultivars in 2013/2014 and 2014/2015 seasons.

\begin{tabular}{|c|c|c|}
\hline Cultivars Season & \multicolumn{2}{|c|}{ Pollen stained red (\%) After 24 h } \\
\cline { 3 - 4 } & $\mathbf{1}^{\text {st }}$ season & $\mathbf{2}^{\text {nd }}$ season \\
\hline Hollywood & 97.232 & 99.187 \\
\hline Pioneer & 96.977 & 90.553 \\
\hline T. test & NS & S \\
\hline
\end{tabular}

\subsubsection{Self-compatibility}

Testing of pollen tube growth in the pistil after self-pollination enables determination of self-compatibility in plum cultivars. Pollen grains placed on the stigma surface begin to germinate and elongate into pollen tubes that grow through the stylar tissue. The walls of the pollen tubes contains callose (1, 3-glucane), which binds with aniline blue during staining. When subjected blue or ultraviolet light they fluoresce, showing a golden yellow color that creates a sharp contrast on a dark background.

3.6.6. Pollen tube characteristics after selfpollination (selfing) of Hollywood cv.

Partial self-incompatibility was observed when Hollywood cv. flowers were pollinated with its pollens. Some of the styles showed normal incompatible cvs. But, Pioneer cultivar has a degree of partial self-incompatibility higher than Hollywood cultivar. Therefore, they need the additional varieties as pollinators, for growing. These results are similar to those obtained by Abd Elaziz (2005) who demonstrated that Eldorado and Durado plum cvs. are selfincompatible while, Santa-Rosa cv, is considered partially self-compatible Fig. (2 A and B).

\subsection{Storability and quality parameters}

Data in Tables $(9,10,11,12,13$ and14) showed the effect of cold storage period (weeks) on fruit physical and chemical characteristics of Pioneer and Hollywood cultivars in both seasons under study.

\subsubsection{Weight loss (\%)}

Weight loss percentage: As shown in Table (9), 

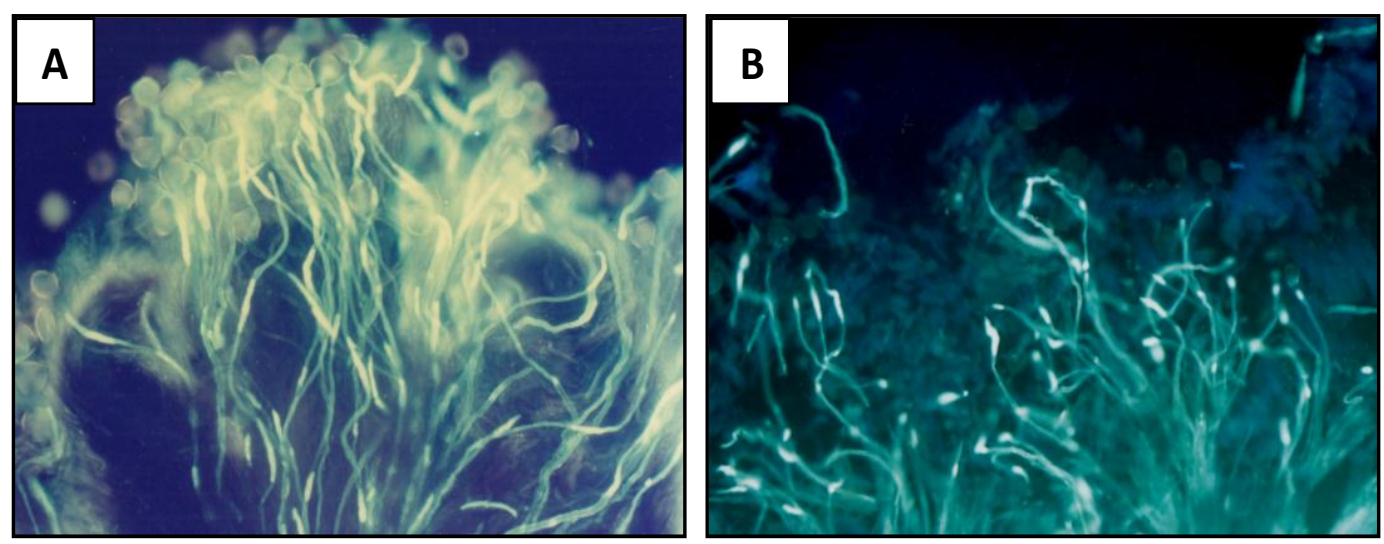

Fig. (2) A:The upper part of pistil with pollen tube characterized by spaced intermittent callose plugs, cultivar Hollywood. (B): The upper part of pistil with pollen tube showed heavy deposition of callose along the tube, cultivar Pioneer.

Table (9): Effect of cold storage period on weight loss (\%) of Pioneer and Hollywood plum fruits in 2013/2014 and 2014/2015 seasons.

\begin{tabular}{|c|c|c|c|c|c|}
\hline \multicolumn{6}{|c|}{$\mathbf{1}^{\text {st }}$ season } \\
\hline \multirow{2}{*}{ Cultivar (C) } & \multicolumn{5}{|c|}{ Days in cold storage } \\
\hline & $\mathbf{0}$ & 7 & 14 & 21 & Means (C) \\
\hline Pioneer & 0.00 & 3.33 & 5.16 & 7.16 & 3.91 \\
\hline Hollywood & $\mathbf{0 . 0 0}$ & 2.49 & 4.55 & 6.61 & 3.41 \\
\hline Means (D) & $\mathbf{0 . 0 0}$ & 2.91 & 4.86 & 6.89 & \\
\hline \multicolumn{6}{|c|}{ new L.S.D. at $0.05 \% \mathrm{C}(0.27), \mathrm{D}(\mathbf{0 . 3 8}), \mathrm{C} \times \mathrm{D}(\mathbf{0 . 5 3})$} \\
\hline \multicolumn{6}{|c|}{$2^{\text {nd }}$ season } \\
\hline \multirow{2}{*}{ Cultivar (C) } & \multicolumn{5}{|c|}{ Days in cold storage } \\
\hline & $\mathbf{0}$ & 7 & 14 & 21 & Means (C) \\
\hline Pioneer & $\mathbf{0 . 0 0}$ & 3.54 & 5.71 & 7.29 & 4.13 \\
\hline Hollywood & 0.00 & 2.68 & 4.83 & 6.94 & 3.61 \\
\hline Means (D) & $\mathbf{0 . 0 0}$ & 3.11 & 5.27 & 7.11 & \\
\hline
\end{tabular}

it was noticed that fruit weight loss (\%) increased gradually till the end of the cold storage period. This increase can be probably due to moisture loss from the fruits during cold storage. Pioneer plum fruit weight loss were significantly higher (7.16 and 7.29\%) than Hollywood plum cultivar which recorded (6.61 and $6.94 \%$ ) after three weeks of cold storage in both seasons respectively. Weight loss is a result of transpiration from the surface of fruits $(\mathrm{Wu}$, 2010).

\subsubsection{Decay (\%)}

The data presented in Table (10) showed that decay did not appear in the first two weeks of cold storage and was detected by the end of cold storage period. Pioneer fruits had significantly higher percentage of decay (5.23 and 5.61\%), while Hollywood plum fruits recorded (4.57 and $4.63 \%$ ) after three weeks of cold storage in both seasons, respectively. The results are supported by the findings of Kruger et al. (2003) on plum cultivars, who found that disorders increased by extending the storage period during cold storage. 
Table (10): Effect of cold storage period on decay (\%) of Pioneer and Hollywood plum fruits in 2013/2014 and 2014/2015 seasons.

\begin{tabular}{|c|c|c|c|c|c|}
\hline \multicolumn{6}{|c|}{$1^{\text {st }}$ season } \\
\hline \multirow{2}{*}{$\begin{array}{l}\text { Cultivar (C) Date (D) } \\
\end{array}$} & \multicolumn{5}{|c|}{ Days in cold storage } \\
\hline & $\mathbf{0}$ & 7 & 14 & 21 & Means (C) \\
\hline Pioneer & 0.00 & $\mathbf{0 . 0 0}$ & $\mathbf{0 . 0 0}$ & 5.23 & 1.31 \\
\hline Hollywood & 0.00 & $\mathbf{0 . 0 0}$ & $\mathbf{0 . 0 0}$ & 4.57 & 1.14 \\
\hline Means (D) & $\mathbf{0 . 0 0}$ & $\mathbf{0 . 0 0}$ & $\mathbf{0 . 0 0}$ & 4.90 & \\
\hline \multicolumn{6}{|c|}{ new L.S.D. at $0.05 \% \mathrm{C}(0.13), \mathrm{D}(0.19), \mathrm{C} \times \mathrm{D}$ ( 0.26) } \\
\hline \multicolumn{6}{|c|}{$2^{\text {nd }}$ season } \\
\hline \multirow{2}{*}{$\begin{array}{r}\text { Cultivar (C) Date (D) } \\
\text { Date }\end{array}$} & \multicolumn{5}{|c|}{ Days in cold storage } \\
\hline & $\mathbf{0}$ & 7 & 14 & 21 & Means (C) \\
\hline Pioneer & $\mathbf{0 . 0 0}$ & $\mathbf{0 . 0 0}$ & $\mathbf{0 . 0 0}$ & 5.61 & 1.40 \\
\hline Hollywood & $\mathbf{0 . 0 0}$ & $\mathbf{0 . 0 0}$ & $\mathbf{0 . 0 0}$ & 4.63 & 1.16 \\
\hline Means (D) & 0.00 & 0.00 & 0.00 & 5.12 & \\
\hline
\end{tabular}

\subsubsection{Firmness (lbA lb/inch $\left.{ }^{2}\right)$}

Table (11), shows that in fruit firmness decreased gradually till the end of the cold storage period. Pioneer fruits had significantly lower fruit firmness (4.02 and $\left.4.27 \mathrm{lb} / \mathrm{inch}^{2}\right)$ than Hollywood plum fruits which recorded $\left(5.83\right.$ and $6.01 \mathrm{lb} /$ inch $\left.^{2}\right)$ after three weeks of cold storage in both seasons respectively. For climacteric fruits, firmness decrease during ripening are generally attributed to the

Table (11): Effect of cold storage period on firmness (Lb/inch2) of Pioneer and Hollywood plum fruits in 2014 and 2015 seasons.

\begin{tabular}{|l|c|c|c|c|c|}
\hline \multicolumn{5}{|c|}{$1^{\text {st }}$ Season } \\
\hline Date (D) & 0 & 7 & 14 & 21 & Means (C) \\
\cline { 2 - 6 } Pioneer & 8.87 & 6.81 & 4.69 & 4.02 & 6.10 \\
\hline Hollywood & 11.94 & 9.58 & 6.99 & 5.83 & 8.59 \\
\hline Means (D) & 10.41 & 8.20 & 5.84 & 4.93 & \\
\hline new L.S.D. at 0.05\% C( 0.32), D ( 0.45), C x D ( 0.63) \\
\hline \multicolumn{5}{|c|}{$2^{\text {nd }}$ Season } \\
\hline Cultivar (C) & \multicolumn{5}{|c|}{ Days in cold storage } \\
\cline { 2 - 6 } Date (D) & 0 & 7 & 14 & 21 & Means (C) \\
\hline Pioneer & 9.13 & 7.01 & 4.79 & 4.27 & 6.30 \\
\hline Hollywood & 12.07 & 9.97 & 6.24 & 6.01 & 8.57 \\
\hline Means (D) & 10.60 & \multicolumn{6}{|c|}{8.49} & 5.52 & 5.14 & \\
\hline new L.S.D. at 0.05\% C( 0.25), D ( 0.36), C x D ( 0.51) \\
\hline
\end{tabular}


degradation of cell walls and loss of turgor pressure in cells due to moisture loss (Khin et al., 2007).

\subsubsection{Skin color}

The data presented in Table (12), indicated that fruit skin color represented by hue angle values decreased gradually till the end of the cold storage period (the more the decrease in hue angle, the more the increase in red color intensity). For both varieties Hollywood cv. recorded significantly lower values of hue angle (the highest red skin color, 24.16 and 21.07), while Pioneer cv. recorded 26.41 and 24.31 after three weeks of cold storage in both seasons, respectively. and $15.42 \%)$ after three weeks of cold storage in both seasons respectively. These results are agreement with Shaarawi et al. ( 2017) who reported that the total soluble solids percentage increased in plum fruit celebration variety during storage, this due to ripening process.

\subsubsection{Total acidity $(\%)$}

The data presented in Table (14), cleared that fruit juice acidity decreased noticeably and gradually till the end of the cold storage period. Hollywood plum cultivar recorded significantly the lowest percentage of fruit juice acidity $(0.62$ and $0.53 \%$ ), while Pioneer plum cultivar acidity recorded $(0.69$ and $0.65 \%)$ after three weeks of cold storage in both seasons respectively. This

Table (12): Effect of cold storage period on skin color (Hue angle) of Pioneer and Hollywood plum fruits in 2014 and 2015 seasons.

\begin{tabular}{|c|c|c|c|c|c|}
\hline & \multicolumn{5}{|c|}{$1^{\text {st }}$ season } \\
\hline Cultivar (C) & 0 & 7 & 14 & 21 & Means (C) \\
\hline Date (D) & & & \multicolumn{1}{|c|}{ Days in cold storage } \\
\hline Pioneer & 34.21 & 28.67 & 26.53 & 26.41 & 28.96 \\
\hline Hollywood & 27.59 & 26.09 & 25.72 & 24.16 & 25.89 \\
\hline Means (D) & 30.90 & 27.38 & 26.13 & 25.29 & \\
\hline new L.S.D. at 0.05\% C ( 0.59), D ( 0.83), C x D (1.18) \\
\hline \multicolumn{5}{|c|}{$2^{\text {nd }}$ season } \\
\hline Cultivar (C) & \multicolumn{5}{|c|}{ Days in cold storage } \\
\hline Date (D) & 0 & 7 & 14 & 21 & Means (C) \\
\hline Pioneer & 41.06 & 33.87 & 27.19 & 24.31 & 31.61 \\
\hline Hollywood & 32.27 & 25.42 & 22.65 & 21.07 & 25.35 \\
\hline Means (D) & 36.67 & 29.65 & 24.92 & 22.69 & \\
\hline new L.S.D. at 0.05\% C ( 0.75), D (1.06), C x D (1.51) \\
\hline
\end{tabular}

These results are in harmony with those obtained by EL-Etreby (2010) who found that hue angle value decreased gradually for Golden Japanese and Santa Rosa cultivars during storage, this means that yellow and red color increased with fruit ripening.

T.S.S. \%: It is obvious from Table (13), that fruit juice TSS (\%) increased significantly and gradually till the end of the cold storage period. This increase may be due to moisture loss from the fruits during cold storage. Hollywood plum fruit juice TSS values were higher (16.79 and $16.46 \%)$ than Pioneer plum fruit values (15.63 may due to that organic acids are important as sources of respiratory.

These results are in concordance with those obtained by shaarawi et al., 2017 on celebration variety.

In conclusion, from the obtained results for Pioneer and Hollywood plum cultivars, it can be concluded that they are characterized by early fruit maturity with good fruit characteristics. Therefore, it is recommended to make widespread cultivation of these cultivars in Egypt. 
Table (13): Effect of cold storage period on the total soluble solids (\%) of Pioneer and Hollywood plum fruits in 2014 and 2015 seasons.

\begin{tabular}{|c|c|c|c|c|c|}
\hline \multicolumn{6}{|c|}{$\mathbf{1}^{\text {st }}$ season } \\
\hline \multirow{2}{*}{ Cultivar (C) Date (D) } & \multicolumn{5}{|c|}{ Days in cold storage } \\
\hline & $\mathbf{0}$ & 7 & 14 & 21 & Means (C) \\
\hline Pioneer & 15.32 & 15.41 & 15.49 & 15.63 & 15.46 \\
\hline Hollywood & 16.37 & 16.54 & 16.63 & 16.79 & 16.58 \\
\hline Means (D) & 15.85 & 15.98 & 16.06 & 16.21 & \\
\hline \multicolumn{6}{|c|}{ new L.S.D. at $0.05 \%$ C (0.08), D ( 0.11), C x D ( 0.15) } \\
\hline \multicolumn{6}{|c|}{$2^{\text {nd }}$ season } \\
\hline \multirow{2}{*}{$\begin{array}{r}\text { Cultivar (C) } \\
\text { Date (D) }\end{array}$} & \multicolumn{5}{|c|}{ Days in cold storage } \\
\hline & $\mathbf{0}$ & 7 & 14 & 21 & Means (C) \\
\hline Pioneer & 15.09 & 15.21 & 15.38 & 15.42 & 15.28 \\
\hline Hollywood & 16.13 & 16.25 & 16.37 & 16.46 & 16.30 \\
\hline Means (D) & 15.61 & 15.73 & 15.88 & 15.94 & \\
\hline
\end{tabular}

Table (14): Effect of cold storage period on the total acidity (\%) of Pioneer and Hollywood plum fruits in 2014 and 2015 seasons.

\begin{tabular}{|l|c|c|c|c|c|}
\hline \multicolumn{7}{|c|}{$1^{\text {st }}$ season } \\
\hline Cultivar (C) Date (D) & 0 & 7 & 14 & 21 & Means (C) \\
\hline Pioneer & 1.63 & 1.34 & 1.13 & 0.69 & 1.20 \\
\hline Hollywood & 1.51 & 1.27 & 1.07 & 0.62 & 1.12 \\
\hline Means (D) & 1.57 & 1.31 & 1.10 & 0.66 & \\
\hline new L.S.D. at 0.05\% C ( 0.03$),$ D ( 0.05), C x D ( 0.06) & \\
\hline \multicolumn{7}{|c|}{$2^{\text {nd }}$ season } \\
\hline Cultivar (C) & \multicolumn{7}{|c|}{ Days in cold storage } & \\
\hline Pioneer & 0 & 7 & 14 & 21 & Means (C) \\
\hline Hollywood & 1.66 & 1.39 & 1.04 & 0.65 & 1.19 \\
\hline Means (D) & 1.57 & 1.25 & 0.94 & 0.53 & 1.07 \\
\hline new L.S.D. at 0.05\% C ( 0.05$),$ D ( 0.08), C x D ( 0.11) & 0.59 & \\
\hline
\end{tabular}




\section{Acknowledgment}

Sincere thanks to Dr. Magda Mohamed Nasr who provided financial support for this study.

\section{REFERENCES}

A.O.A.C. (2000). Association of Official Analytical Chemists, Washington D.C., International $17^{\text {th }}$ Edition, Revision I. USA P. 495-510.

Abd Elaziz Y. G. (2005). Studies on sex compatibility and fruit set of some plum cultivars. Ph. D. Thesis, Fac. Agric. Ain Shams Univ., Cairo Egypt.

Abdel-Sattar M., Marzouk H., Al-Sabrout M.(2013). Enhancement of Hollywood plum setting, retention and fruit quality $\mathrm{J}$. of Appl. Sci. Res., 9(6): 4125-4131.

Burgos L., Egea J., R., Guerriero R., Viti P. M. and Audergon J.M. (1997). The selfcompatibility trait of the main apricot cultivars and new selections from breeding programmes. J. Hort. Sci., (72): 147-154.

Carter M., Rom C.R. and Striegler R.K. (2003). Early performance of peach cultivars in South-West Arkansas. AAES Research Series (520), Hort. Studies, pp: 14-17.

EL-Etreby S. M.A. (2010). Physiological studies on post harvest handling and storage of plum fruits. Ph. D. Thesis, Fac. Agric., Cairo Univ.,Giza Egypt.

Khalil B.M. and El-Sheik A. (2000). Comparative study between two apricot cultivars in relation with protein profile. J. Agric. Sci. Mansoura Univ., 25:3559-3568.

Khin M.M., Zhou W. and Yeo S.Y. (2007). Mass transfer in the osmotic dehydration of coated apple cubes by using maltodextrin as the coating material and their textural properties. J Food Eng., 81: 514-22.

Kho Y.O. and Baer J. (1968). Observing pollen tubes by means of fluorescence. Euphotic, 17:298-302.

Kruger L., Cook N. and Holcroft D. M. (2003). Quality of Japanese plum as influenced by time of harvest and rate of ethylene production. Acta Hort., 600: 453-456.

Ministry of Agriculture, and Land Reclamation Statistics. (2015). Egypt.

Maklad M. F. and Ismaile S.A. (2016). Evaluation of Pioneer and Celebration plum cultivars under El- Khatatba region condition. J. Plant Prod., Mansoura Univ., 7 (7) : $763-767$.
Martin F.W. (1959). Staining and observing pollen tubes in the style by means of fluorescence. Stain Tech.,34:125-128.

MCguire R. G. (1992). Reporting objective color measurements. Hort. Sci., 27(12): 12541255.

Nyéki J. and Z. Szabó (1996). Fruit set of plum cultivars under Hungarian ecological conditions. Acta Hort., 423: 185-192.

Oberle G.D. and Watson R. (1953). The use of 2,3,5-triphenyl tetrazolium chloride in viability tests of fruit pollens. Proc. Amer. Soc. Hort. Sci., 61:299-303.

Pejkić B. (1978). Productivity and nonproductivity of fruit tree species. Nolit, Beograd.

Perez G.M.B., Navarro M. and Del M.A. (2004). Effect of hydroxypropyl methylcelluosebeeswax edible composite coating on plum (cv. Aneleno) quality during storage. $5^{\text {th }}$ International postharvest symposium, Verona, Italy, 6-11 June, pp.133.

Shaarawi S. A. M. A., Mshraky A. M. and ElKady A. T. M (2017). Effect of postharvest safe treatments on quality attributes and storage life of "Celebration" plum fruits. Middle east J. Agric. 06: (01): 24-32.

Snedecor G. W. and Cochran W.G. (1980). Statistical Methods. $7^{\text {th }}$ ed., The Iowa State Univ. Press., Ames., Iowa, U.S.A., pp. 593.

Steel R.G.D. and Torrie F. H. (1980). Principles and Procedures of Statistics. $2^{\text {nd }}$ Edn. McGraw Hill Book Co., New York., U. S. A.

Surranyi D. (1976). Differentiation of self-fertility and self-sterility in Prunus by stamen number/pistil length ratio. Hortiscience, 11:406-407.

Szabó Z. (2003). Plum (Prunus domestica L.). In Floral biology, pollination and fertilisation in temperate zone fruit species and grape“. Akadémiai Kiado, Budapest, pp. 383-410.

Thanaa Sh. M., Kassim N. E., AbouRayya M.S. and Abdalla A. M.(2017). Influence of Foliar Application with Moringa (Moringa oleifera L.) leaf extract on yield and fruit quality of Hollywood plum cultivar. J. of Hort., 4: 4-1. ISSN: 23760354.

Vangdal E., Flatland S. and Nordbo R. (2007). Fruit quality changes during marketing of new plum cultivars. Hort. Sci. (Prague), 34:91-95. 
Viti R., Monteleone P. and Guerriero R. (1997). Incompatibility in apricot (Prunus armeniaca L.): Methodological considerations. J. Hort. Sci., 72(6): 961-970.

Webster A.D. and Spencer J.E. (2000). Fruit thinning, plums and apricots. Plant Grow. Reg., 31: 101-112.

Wertheim S.J. (1996). Methods for cross pollination and flowering assessment and their interpretation. Acta Hort., 423:237-243.

Wu C.T. (2010). An overview of postharvest biology and technology of fruits and vegetables.Technology on Reducing
Post-harvest Losses and Maintaining Quality of Fruits and Vegetables. Proceedings of 2010 AARDO Workshop. Taiwan Agricultural Research Institute, Council of Agriculture, Taiwan, ROS. 3-9 October 2010, pp: 2-11.

Yehia T.A., Hussien A.M., Hegazi A.A. and Hussien H.H.K. (2010). Evaluation of some newly cultivated peach cultivars (Prunus persica L.) under desert conditions of Egypt. J. Biol. Chem. Environ. Sci., 5(1): 299-315.

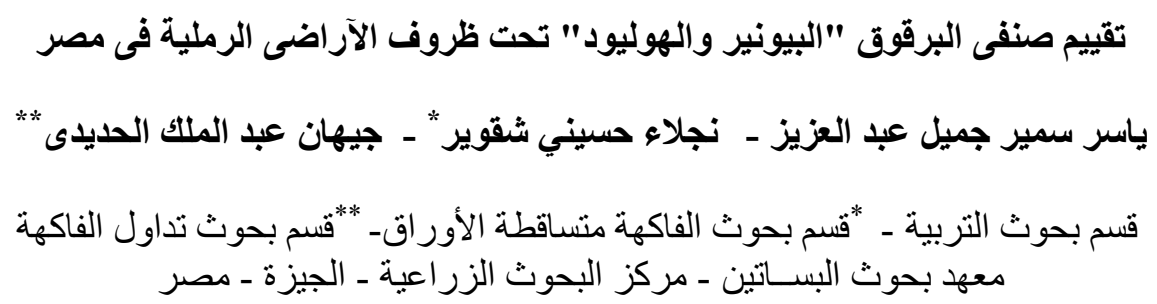

أجرى هذا البحث لمدة موسمين متتاليين (2013 -2014 \لخصا 2014- 2015) بأحد المزارع الخاصة بمنطقة ريجوا

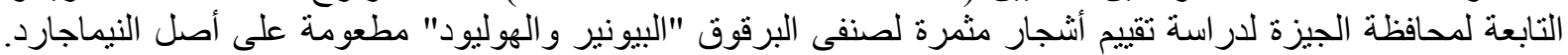

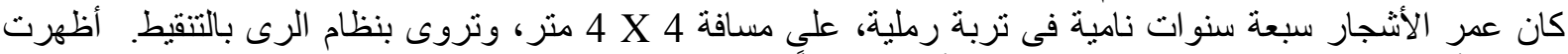

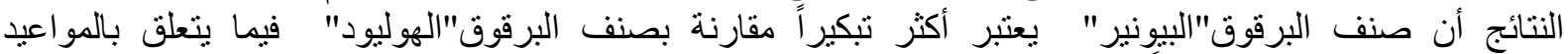

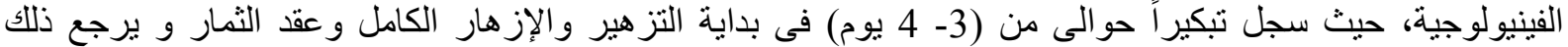

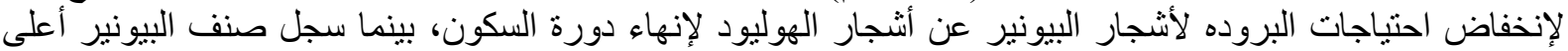

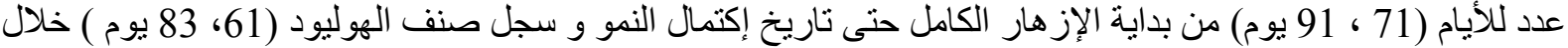

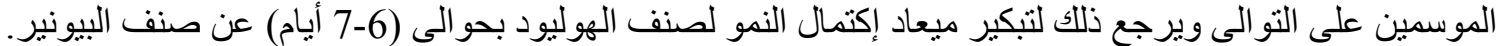

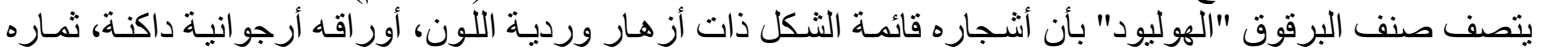

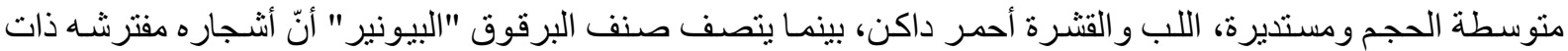

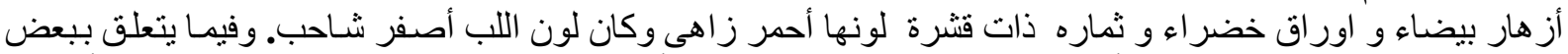

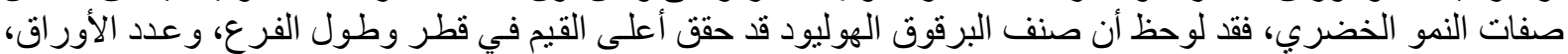

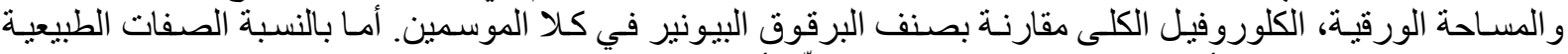

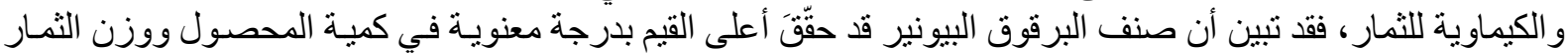

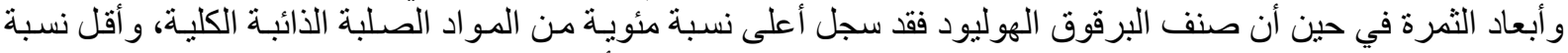

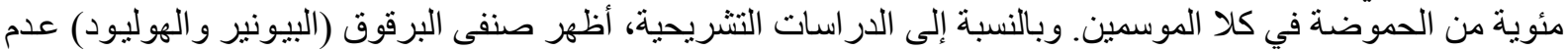

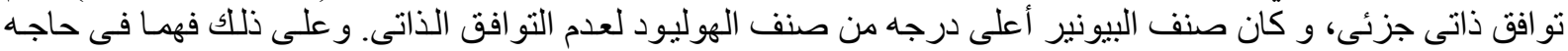

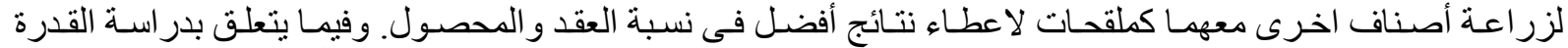

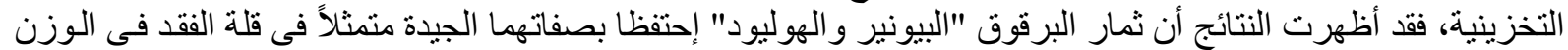

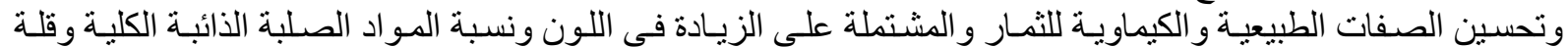

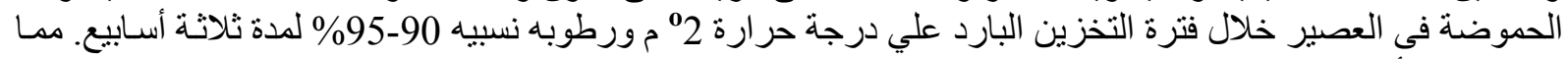

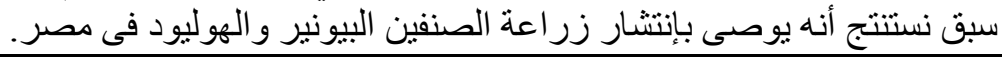

